\title{
USING DYNAMIC LIGHT SCATTERING FOR MONITORING THE SIZE OF THE SUSPENDED PARTICLES IN WASTEWATER
}

Dan CHICEA * and Silviu Mihai REI **

* "Lucian Blaga" University of Sibiu, Faculty of Sciences, Dr. Ion Raţiu Street 5-7, Sibiu, Sibiu County, Romania, RO-550012, dan.chicea@ulbsibiu.ro

** "Lucian Blaga" University of Sibiu, Faculty of Sciences, Research Center for the Physics of Complex Systems, Dr. Ion Raţiu Street 5-7, Sibiu, Sibiu County, Romania, RO-550012/Continental Automotive Systems, Salzburg Street 8, Sibiu, Sibiu County, Romania, RO-550018, silviu.rei@continental-corporation.com

DOI: 10.2478/trser-2019-0015

KEYWORDS: wastewater, coherent light scattering, Dynamic Light Scattering (DLS), artificial neural network.

\section{ABSTRACT}

A coherent light scattering experiment on wastewater samples extracted from several stages of water processing within a wastewater processing plant was carried out. The samples were allowed to sediment while they were the subject of a Dynamic Light Scattering (DLS) measurement. The recorded time series were processed using an Artificial Neural Network based DLS procedure to produce the average diameter of the particles in suspension. The method, using a single physical procedure for monitoring the variation of the average diameter in time, indicates the dominant type of suspensions in water.

ZUSAMMENFASSUNG: Verwendung der dynamischen lichtverwertung zur überwachung der grösse der abhängigen teilchen im abwasser.

Es wurde ein kohärentes Lichtstreuungsexperiment an Abwasserproben durchgeführt, die aus mehreren Stufen der Wasseraufbereitung innerhalb einer Abwasseraufbereitungsanlage entnommen wurden. Die Proben konnten sich sedimentieren, während sie einer dynamischen Lichtstreuungsmessung (DLS) unterzogen wurden. Die aufgezeichneten Zeitreihen wurden unter Verwendung eines DLS-Verfahrens auf Basis eines künstlichen neuronalen Netzwerks verarbeitet, um den durchschnittlichen Durchmesser der in Suspension befindlichen Teilchen zu erzeugen. Das Verfahren, bei dem ein einziges physikalisches Verfahren zur Überwachung der zeitlichen Änderung des durchschnittlichen Durchmessers verwendet wird, zeigt den vorherrschenden Typ von Suspensionen in Wasser an.

REZUMAT: Folosirea împrăştierii dinamice a luminii pentru monitorizarea dimensiunii medii a particulelor aflate în suspensie în apa reziduală.

A fost efectuat un experiment de împrăştiere a luminii coerente pe probe de apă reziduală prelevate din diferite locații ale unei stații de tratare a apei reziduale. Probele au fost lăsate să se sedimenteze, timp în care au fost subiectul unui experiment de împrăștiere dinamică a luminii. Seriile temporale înregistrate au fost prelucrate folosind un procedeu simplificat de dnamică a împrăştierii luminii asistat de o rețea artificială neuronală care a determinat dimensiunea medie a particulelor în suspensie. Metoda care folosește un singur procedeu fizic, oferă informații despre tipul particulelor din suspensie. 


\section{INTRODUCTION}

Wastewater is one of the predominant environmental problems, due to the input of different substances (Oprean and Olosutean, 2011). The waste water treatment is one of the significant main elements in maintaining the quality of a wide variety of aquatic habitats and ecosystems in the present human society circumstances; the substance types and their concentrations in some effluents are main problems in the matter, leading to the alteration of oxygen balances, eutrophication, and major modifications in wildlife composition, inducing a threat to many aquatic species (Ansari et al., 2010; Gjyli and Mukli, 2009; Khoshnood and Khoshnood, 2015; Khuram et al., 2019; Wedyan et al., 2019).

A proper treatment of such wastewater pollutants including those in suspended form cannot be obtained in the absence of specific identification methods, including the size of suspended particles in wastewater. This identification is important in choosing specificadapted wastewater treatment methods. Developing such an identification method is the main goal of the present study.

Any natural water, also the wastewater, is partially opaque. The partial opacity is caused by the particles suspended in it, which scatter and absorb light. This physical property is called turbidity $(*, 2002)$. Some of the particles in suspension consist of sand, clay, silt, plankton, algae, micro-organisms, as in natural water in ponds and rivers $(* *, 2006)$. Wastewater can also contain human feces and urine, mixed with used toilet paper, in which case the wastewater is named blackwater (Tilley et al., 2014). Wastewater can also contain washing water, in which case it is known as greywater or sullage (Tilley et al., 2014) or manufactured liquids from domestic sources. Wastewater is ussualy treated in a wastewater treatment plant and released into a receiving water body, typically a river.

The parameter that describes the fact that water is not fully transparent, is called turbidity and is related to the total amount of suspended material in water $(*, 2002)$. As stated in previous work (Chicea, 2013a, b) turbidity is not a measure of the concentration or of the size of the particles. Moreover, measuring and knowing turbidity does not provide good knowledge regarding the size and the type of particles. As already stated (Chicea, 2013a, b), a good knowledge of the size and the type of the suspended particles is important.

If the suspended particles scatter light in an elastic manner, there are no changes produced in water, but if the particles absorb light, this causes a temperature increase in turbid water. Under the same light exposure turbid water is warmer than less turbid (less opaque) water. Water temperature is a tremendously important parameter in an ecosystem. Gumpinger et al. (2010) stated that water temperature is considered one of the most essential regulating parameters in aquatic ecosystems. Moreover, because of the intensive interrelations with other physical and chemical parameters, water temperature has a high indicative value when considering the general condition of a river ecosystem (Gumpinger et al., 2010).

The work presented here is a continuation of the previous work (Chicea, 2013a, b; Chicea and Chicea, 2015) aiming to assess the type of suspension in natural water (organic or inorganic) using a combination of two physical procedures: sedimentation and Dynamic Light Scattering (DLS hereafter). The novelty consists in making the time series processing much faster by using an Artificial Neural Network (ANN hereafter) and details and results are presented in the following sections. 


\section{MATERIAL AND METHODS}

\section{Particles sedimentation}

When a particle is suspended in a fluid, as a suspension particle in natural or wastewater is, it is subject to the action of three forces: gravity, buoyant force and the Stokes drag, if the motion of the particle takes place in the laminar regime (Chicea, 2008). Details on the three forces have been extensively presented in (Chicea and Chicea, 2015) in the first four equations and in the first two figures. They will therefore not be repeated here.

If the density of the particle, $\rho$, is different from the density of the fluid, $\rho_{0}$, the particle will start moving and the velocity $\mathrm{v}$ will increase. As the velocity increases, so does the Stokes drag, up to the point that makes the sum of the three forces null, as illustrated in figure 1 and equation 4 (Chicea and Chicea 2015). The limit velocity of falling is reached and kept constant thereafter. The limit velocity $\mathrm{v}_{\mathrm{l}}$ is given by equation (1), where $\mathrm{R}$ is the radius of the particle, $g$ is the gravitational acceleration and $\eta$ is the coefficient of dynamic viscosity of the fluid.

$$
v_{l}=\frac{2\left(\rho-\rho_{0}\right) R^{2} g}{2 \eta}
$$

If the density of the particle, $\rho$, is bigger than $\rho_{0}, \mathrm{v}_{1}$ is oriented downwards; if $\rho$ is smaller than $\rho_{0}, v_{l}$ is oriented upwards, and if they are equal the particle is in static equilibrium.

The limit velocity can be used to assess the type of the particles that are still suspended in the fluid after a certain time from the beginning of the experiment, if we have a procedure to measure the diameter of the particles, such as DLS for instance. For this purpose, we can consider a cuvette with the suspension as in figure 2 (Chicea and Chicea, 2015). All the particles that were located above the mark at the beginning of the experiment (hereafter at time 0 ) will fall below the laser beam level in time $t$ if they have a velocity bigger than $v_{m}(t)$, given by equation (2):

$$
v_{m}(t)=\frac{L}{t}
$$

This means that at time $t$, only the particles having a velocity smaller than $\mathrm{v}_{\mathrm{m}}(\mathrm{t})$ in equation (6), are remaining in suspension, above the line and, hence a diameter smaller than $\mathrm{d}_{\max }$ found by inverting equation (2):

$$
d_{\max }=2 \cdot R_{\max }=\sqrt{\frac{9 \eta v_{m}}{2\left(\rho-\rho_{0}\right) g}}
$$

A plot of the $d_{\max }$ versus time, considering $\mathrm{L}=$ one $\mathrm{cm}$, as was used in the work described here, and the suspensions to be silt or sand, with a density $\rho=2,600 \mathrm{~kg} / \mathrm{m}^{3}$, is presented in figure 3 (Chicea and Chicea, 2015) and is therefore not repeated here.

These considerations allow us to assess the type of suspensions in water, together with another complimentary procedure to measure the diameter of the particles at time t, which is the ANN assisted DLS procedure that is described in the following subsection. The conclusions of (Chicea and Chicea, 2015) highlight that if particles are silt and sand, the diameter in the beam area will monotonously decrease in time; if the diameter suddenly increases it is an indication that the silt and sand has sedimented and only organic particles and bacteria remained in the beam area and if the diameter remains constant the suspension consists of organic particles mainly. 


\section{The reference DLS procedure}

DLS is an optical procedure used for assessing the size of the particles in suspension (Clark, 1970; Berne and Pecora, 2000; Chicea, 2010). When coherent light crosses a medium having scattering centers (SC) an in-uniformly illuminated image is obtained, called the speckle image, as explained in a report of previous work on this subject (Chicea, 2013a, b; Chicea and Chicea, 2015). The image is not static but changes in time giving the aspect of "boiling speckles” (Goodman, 1984; Briers, 2001).

As the SCs are moving, the image presents intensity fluctuations in each location. If we place a detector in a certain location, the time variations of the intensity are recorded and a time series is the result. The schematic of the experimental setup is the same as in (Chicea and Chicea, 2015) except that the scattering angle was chosen to be $90^{\circ}$.

The power spectrum of the intensity of the light scattered by particles in suspension can be linked to the probability density function (Clark, 1970; Tscharnuter, 2000). This link between the PDF and the power spectrum is a consequence of the translation of the relative motion of the scattering particles into phase differences of the scattered light. By subtracting the average intensity from the recorded time series and calculating the square of the intensity we obtain the power time series. The Fourier transform of the power time series is the power spectrum.

We can compare the spectrum numerically computed from the experimental data with the theoretically expected spectrum, which is the Lorentzian line S(f) (4), (Clark et all, 1970, Chicea and Rei, 2018). S(f) has two free parameters $a_{0}$ and $a_{1}$ and is fit to the power spectrum using a least square minimization procedure. Once the fit is completed, the diameter of the SCs can be assessed as the double of the radius $\mathrm{R}$.

$$
S(f)=a_{0} \frac{a_{1}}{(2 \pi f)^{2}+a 1^{2}}
$$

The radius can be derived as a function of the fitted parameter $\mathrm{a}_{1}$ and other known quantities using (5) and further details are presented (Chicea, 2017; Chicea and Rei, 2018).

$$
R=\frac{2 k_{B} T K^{2}}{6 \pi \eta a_{1}}
$$

The wavelength was $633 \mathrm{~nm}$, the light source was a He-Ne laser and the power was $10 \mathrm{~mW}$. The scattering angle $\theta$ was chosen to be $90^{\circ}$, different from the value of $4^{\circ} 58^{\prime} 11^{\prime \prime}$ which was used in Chicea and Chicea (2015). Consequently, the data acquisition rate was changed to $16 \mathrm{kHz}$, and this combination increased the accuracy of the diameter measurement considerably. This DLS procedure based on fitting the Lorentzian line to the PSD to determine the average diameter was considered the reference procedure and for testing and validating the ANN based DLS, which is presented briefly in the next subsection.

\section{ANN based DLS time series processing}

For each particle size there is a corresponding Lorentzian line, therefore we can naturally conclude that solving the particle size problem for a range of sizes is equivalent to finding the function for fitting the power spectrum of the recorded time series. The function we selected as input for the neural network is the autocorrelation function of the time series recorded.

$$
R_{x}(t) \equiv \lim _{T \rightarrow \infty} \frac{1}{T} \int_{0}^{\infty} x(t) x(t+\tau) d t
$$


The problem can be reduced to fitting the autocorrelation function of the time series, rather than fitting the Lorentzian line, simply because the PSD and the autocorrelation are not independent of each other, according to the Wiener-Khinchin Theorem (Weisstein, 2018).

The alternative of using the autocorrelation to be fitted is an advance, as compared to the reference method. Due to sensors calibration, a time series can have various amplitudes, for the same particle size, when measurements are taken with different equipment or a different calibration. This will be reflected in the power spectral density, in the amplitudes corresponding to various frequencies. The autocorrelation function creates a cleaner input for the neural network and does not depend on the amplitudes, but on how fast the time series decorrelates. And this, reflected in the correlation time, is connected to the particle size, a connection which can be revealed by a properly trained and designed neural network. Our analysis which follows will be based on an algorithm for mono-disperse systems of particles. When using the normalized autocorrelation function, scaling the PSD is no longer required, because the function will be normed to one and decay to zero when time increases.

The schematic of the ANN based DLS time series processing is presented in figure 1 . The Matlab package was used in generating and training the ANN which was an ANN for fitting type, having three layers, as previously described. The first (input) layer had 350 neurons, the hidden layer had 26 neurons and the third (output) layer had one neuron, as the output is the average diameter. Details on designing the ANN, on generating the set of training data and on testing the performance of the procedure are extensively presented in (Chicea and Rei, 2018). Overall, the ANN based DLS time series processing procedure proved to be thousands of times faster than the reference DLS procedure, once the time series is recorded. The results presented in the corresponding section were done using the ANN based procedure described in this subsection.

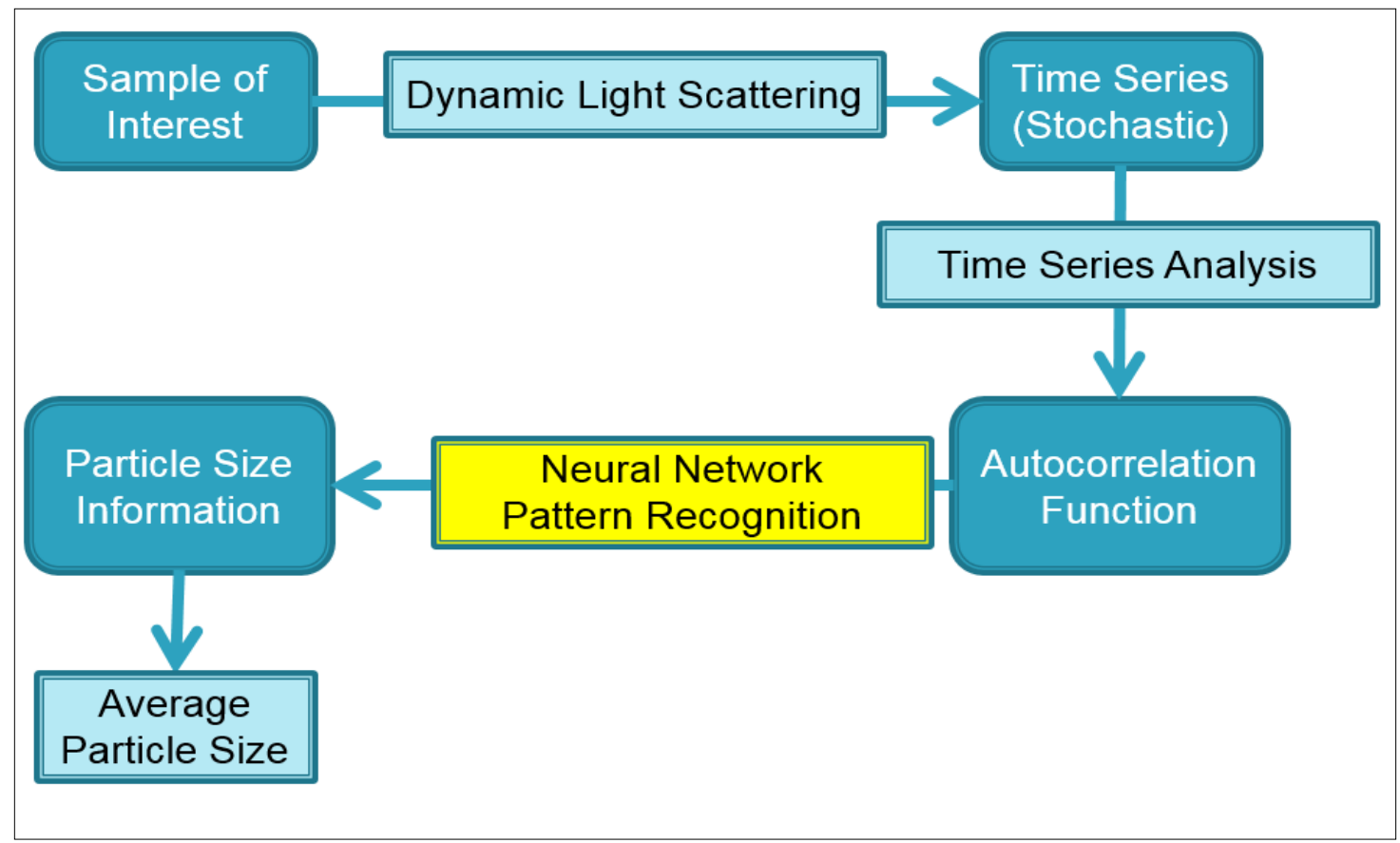

Figure 1: The schematic of the ANN based DLS time series processing. 
The ANN that was used in time series processing for the work reported here is different from the ANN used in (Chicea and Rei, 2018). The number of neurons in the layers was the same, but the set of training data was considerably bigger, covering the diameter range 10-3,000 $\mathrm{nm}$. The diameters computed using the ANN were compared with the diameters computed using the reference DLS method described in the previous subsection and were found to be accurate within $2 \%$ in the training range. The diameters were less accurate outside the training area that is within $15 \%$ for diameters of $5,000 \mathrm{~nm}$. We should note that the reference DLS method is not precise for diameters bigger than 3,000 nm, therefore the diameters computed with the ANN, which are bigger that 3,000 nm, should be viewed as halfquantitative assessment rather than a precise measurement.

\section{Experimental procedure and data processing}

Wastewater samples from several locations within the wastewater processing plant at Mohu, Sibiu (the plant, hereafter) were taken and each one was placed in the circular cuvette having a diameter of $0.8 \mathrm{~cm}$. Figure 3 illustrates the schematic of the plant and the location of sampling water.

At location one, the untreated water was used for measurement. At location two, water which went through the screen grit chamber and aeration tank, active sludge was used for measurements. At location three the water which went through final sedimentation was used for measurements. Samples of water from the three mentioned locations were taken and measurements for a short duration (five minutes) and a long duration (10 hours) were made. For the short duration, time series were recorded every 10 seconds. For the long time duration, time series were recorded every 20 minutes.

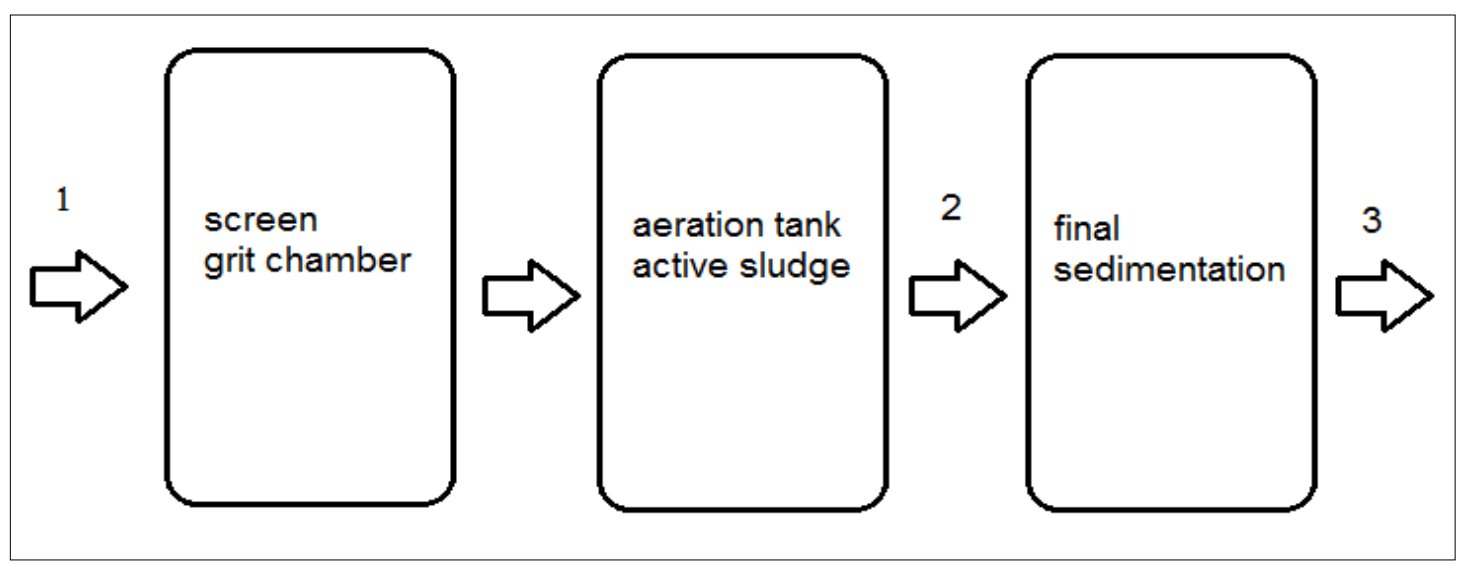

Figure 2: The schematic of the plant and the location of sampling water.

\section{RESULTS AND DISCUSSION}

Figure 3 reveals the average particle size estimated during different stages of wastewater processing. The wastewater at input, sampled at location one, contains sand, silt and organic suspensions. The average diameter estimated was $4,700 \mathrm{~nm}$. It is worth noting that the input water is already pre-filtered so that the big particles have been removed. After sedimentation, only the organic particles remained in the aeration tank. After about seven eight hours average time spent in the aeration tank with aerobic bacteria, the size of the remaining particles were about $660 \mathrm{~nm}$. This is visible in the measurement at location two. At location three, the water exits the sedimentation tank having smaller particles of with an average diameter of $550 \mathrm{~nm}$. 


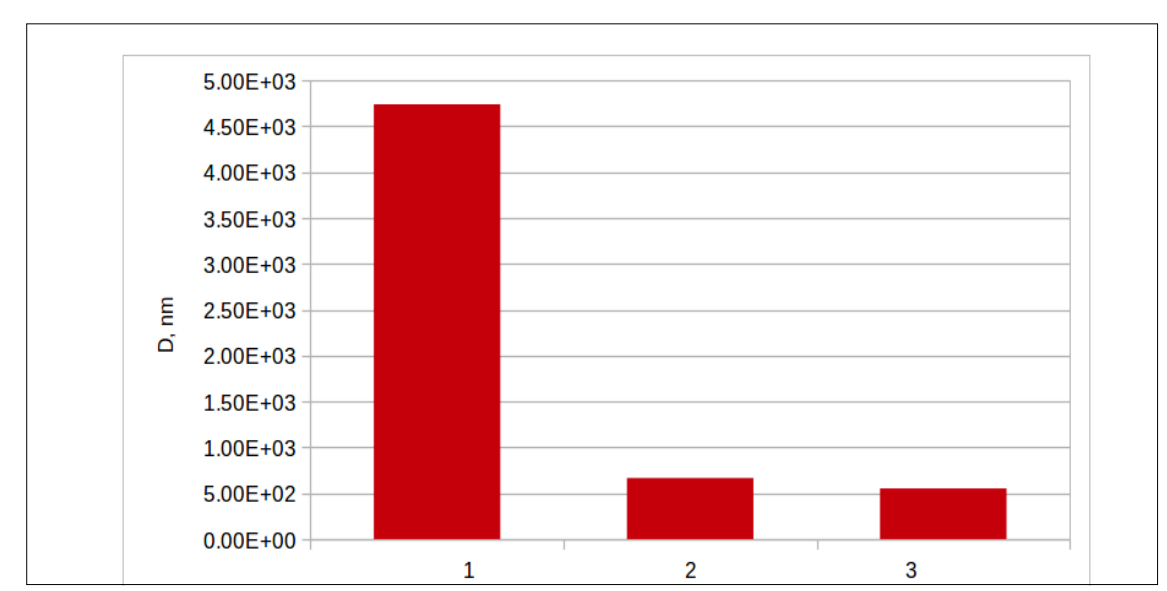

Figure 3: Medium size of suspended particles during different stages of wastewater processing.

At location one, the short time monitoring shows a fast sedimentation of the inorganic particles which initially dominate the measurement as they are in much higher numbers. As soon as their numbers decrease, the organic particles, which do not sediment, as they have a density equal to the water density, start to dominate the measurement (Fig. 4).

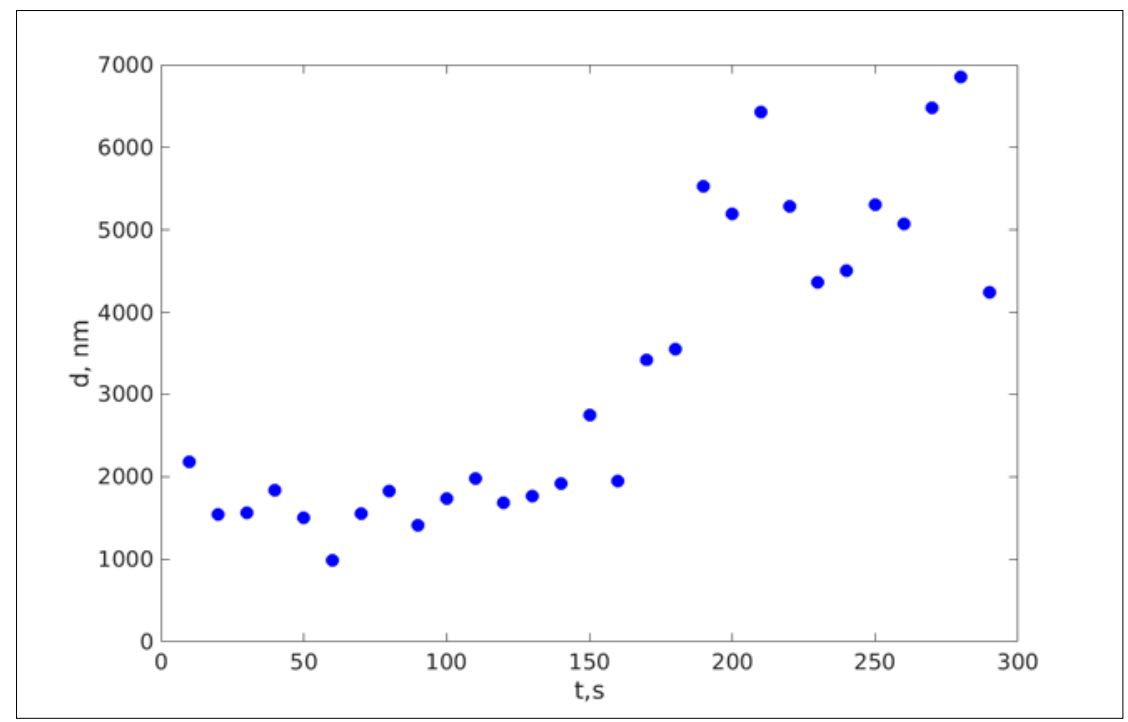

Figure 4: The short time variation of the average diameter of the suspended particles in time from treated water samples at the exit of the plant, in location one.

This is the reason for the jump from low particle size value to a higher value in about 150 seconds. In the long time monitoring at location one the organic particles remain in the water, which makes sense as the water did not undergo the stages of the treatment meant to reduce the organic content. At location two, the short time monitoring reveals that there are inorganic particles that dominate the measurement, most likely particles which were not filtered 
out and were moved in the water movement through tanks. In the long time monitoring it can be seen that these particles sediment and the size tend to decrease slowly. This is consistent with the treatment stage which involves mixing the water with active sludge which has small particles and bacteria in higher concentration.

Figure 5 illustrates the variation of the average diameter of the suspended particles in time from treated water samples at the exit of the plant, in location three.

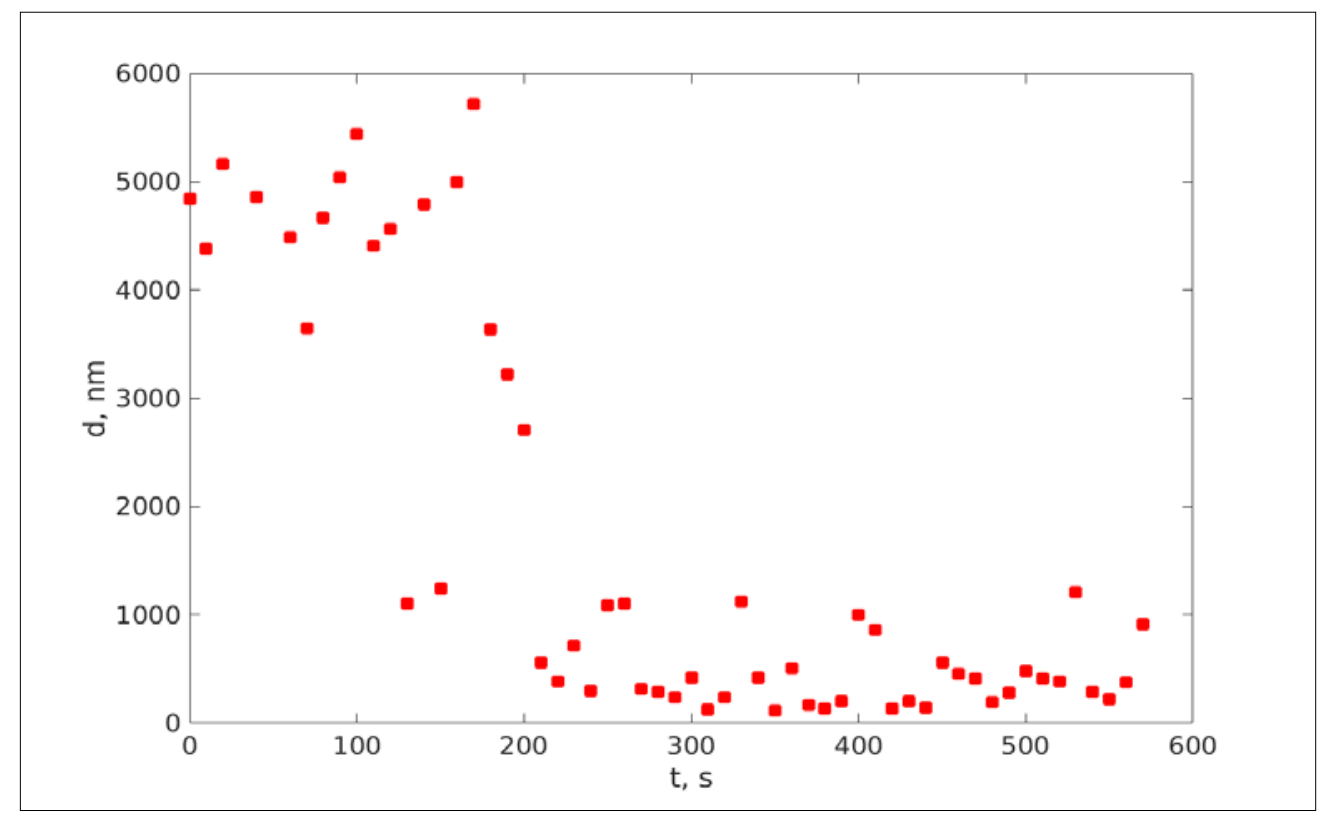

Figure 5: The short time variation of the average diameter of the suspended particles in time from treated water samples at the exit of the plant, in location three.

At location three, the exit of the plant, there is a smaller amount of particles but with a mixture of sizes in the low range. The evolution of sizes can be explained noting that the measurement takes place for the particles in the scattering volume, in the way of the laser beam. The result is consistent with particles which are organic but have a density slightly smaller than water. As time passed, particles drifted towards surface. Smaller particles drifted also but with a smaller velocity. In the end, a small number of organic particles with big diameters still remain in wastewater after processing.

\section{CONCLUSIONS}

Using the combination of DLS with sedimentation is a simple and reliable tool that can be used in describing the type of suspension in natural water. The combined DLS - sedimentation procedure outputs the average diameter of the particles and the type of particles that can be found in suspension, without requiring calibration. The novel procedure described in this work is a traditional DLS with the time series processing performed with an ANN. The ANN is designed and trained just once, using a big set of input data of autocorrelations in this case, with known diameters. The process of generating the training data and of training the ANN is laborious and time consuming, but this process is performed just once. Processing the autocorrelations later on using the ANN is thousands of times faster and much less computation intensive (Chicea and Rei, 2018), therefore it can be exported to a light computing platform like a tablet or smart-phone, making thus the DLS particle seizer much faster and more portable. 


\section{ACKNOWLEDGEMENTS}

We are especially indebted to Ms. Maier and Ms. Filip from Apa-Canal Sibiu S. A. for their direct help and fruitful discussions. The work presented in this article was in part financed from "Lucian Blaga” University of Sibiu research grants LBUS-IRG-2017-03.

\section{REFERENCES}

1. Ansari A. A., Gill S. S. and Khan F. A., 2000 - Eutrophication: threat to aquatic ecosystems, in Ansari A., Singh Gill S., Lanza G. and Rast W. (eds), Eutrophication: causes, consequences and control, Springer, Dordrecht, DOI: https://doi.org/10.1007/978-90-481-9625-8_7, ISBN 978-90481-9624-1.

2. Berne B. J. and Pecora R., 2000 - Dynamic Light Scattering: with applications to chemistry, biology and physics, Dover Publications, 10-23.

3. Briers J. D., 2001 - Laser Doppler, speckle and related techniques for blood perfusion mapping and imaging, Physiological Measurement, 22, 35-66.

4. Chicea D., 2008 - Coherent Light Scattering on nanofluids - Computer Simulation Results Applied Optics, 47, 10, 1434-1442.

5. Chicea D., 2010 - Nanoparticles and nanoparticle aggregates sizing by DLS and AFM, Journal of Optoelectronics and Advanced Materials, 4, 9, 1310-1315.

6. Chicea D., 2013a - Estimating particle concentration in natural water by speckle size measurement, Proceedings of 11th International Conference on Environment, Ecosystems and Development (EED’13), Braşov, Romania, June 1-3, 151-161.

7. Chicea D., 2013b - Estimating particle concentration in natural water by speckle contrast, Transylvanian Review of Systematical and Ecological Research, 15.1, 2, 1-10.

8. Chicea D. and Chicea L. M., 2015 - Profiling suspensions in natural water by a simplified dynamic light scattering procedure and sedimentation, Transylvanian Review of Systematical and Ecological Research, 17.2, 1-10.

9. Chicea D., 2017 - Using neural networks for Dynamic Light Scattering time series processing, Measurement Science and Technology, 28, 5, 055206.

10. Chicea D. and Rei S. M., 2018 - A fast artificial neural network approach for Dynamic Light Scattering time series processing, Measurement Science and Technology, 29, 105201, 15, https://doi.org/10.1088/1361-6501/aad937.

11. Clark N. A., Lunacek J. H. and Benedek G. B., 1970 - A study of brownian motion using light scattering, American Journal of Physics, 38, 575-585.

12. Gjyli L. and Mukli L., 2009 - Assessment of water microbiologic pollution in Durres's Harbour basin (Albania), Transylvanian Review of Systematical and Ecological Research, 8, The Wetlands Diversity, 169-184.

13. Goodman J. W., 1984 - Statistical properties of laser speckle patterns, in Laser speckle and related phenomena, 9, in Topics in Applied Physics, Dainty J. C., Edit., Springer-Verlag, Berlin, Heidelberg, New York, Tokyo, 9-75.

14. Gumpinger C., Höfler S., Berg K. and Scheder C., 2010 - Water temperature as an applicable parameter with a high indicative value for the general condition of a river-ecosystem, drawing on the example of the river Trattnach in Upper Austria, Transylvanian Review of Systematical and Ecological Research, 10, The Wetlands Diversity, 1-14.

15. Khoshnood Z. and Khoshnood R., 2015 - Effect of industrial wastewater on fish in Karoon River, Transylvanian Review of Systematical and Ecological Research, 17.1, The Wetlands Diversity, 109-120. 
16. Khuram I., Muhammad Z., Ahmad N., Ullah R. and Barinova S., 2019 - Green and Charophyte algae in bioindication of water quality of Shah Alam River (District Peshawar, Pakistan), Transylvanian Review of Systematical and Ecological Research, 21.1, The Wetlands Diversity, $1-16$.

17. Oprean L. and Olosutean H., 2011 - A new perspective on McKinney's wastewater model, Transylvanian Review of Systematical and Ecological Research, 12, The Wetlands Diversity, 181-202.

18. Tilley E., Ulrich L., Lüthi C., Reymond P. and Zurbrügg C., 2014 - Compendium of sanitation systems and technologies - (2nd revised edition), Swiss Federal Institute of Aquatic Science and Technology (Eawag), Duebendorf, Switzerland, ISBN 978-3-906484-57-0, 7-14.

19. Tscharnuter W., 2000 - in Encyclopedia of Analytical Chemistry, Meyers R. A. (ed.), John Wiley and Sons Ltd., 5469-5485.

20. Weisstein E. W. 2018 - Wiener-Khinchin theorem, from MathWorld - A Wolfram Web Resource, http://mathworld.wolfram.com/Wiener-KhinchinTheorem.html.

21. Wedyan M. A., Qnais E., Altaif K. and Al-Tawaha R., 2019 - Characteristics of dissolved organic nitrogen in municipal and biological nitrogen removal wastewater treatment plants in Jordan, Transylvanian Review of Systematical and Ecological Research, 21.2, The Wetlands Diversity, 1-12.

22. *, 2002 - Waterwatch Australia National Technical Manual, Module 4, Waterwatch Australia Steering Committee, Environment Australia, ISBN 0-6425-4856-0, 19-21.

23. **, 2006 - National Soil Survey Handbook part 618, Soil properties and qualities, United States Department of Agriculture - Natural Resource Conservation Service, 42-55. 